\title{
Phenology of fish spawning in two lakes that are heated to different degrees
}

\author{
Andrzej Kapusta, Elżbieta Bogacka-Kapusta
}

Received - 04 May 2015/Accepted - 05 January 2016. Published online: 30 June 2016; @Inland Fisheries Institute in Olsztyn, Poland Citation: Kapusta A., Bogacka-Kapusta E. D. 2016 - Phenology of fish spawning in two lakes that are heated to different degrees - Arch. Pol. Fish. 24: 107-110.

\begin{abstract}
The aim of this paper is to present the results of studies on the phenology of the spawning of fish in two lakes with different degrees of heated waters. The studies performed indicated that heating the waters distinctly hastened fish spawning in comparison to the same species of fish inhabiting waters with normal thermal conditions. Spawning usually occurred two to three weeks earlier in the heated Lake Licheńskie than it did in Lake Slesińskie, which has waters with a natural thermal regime. Additionally, it was noted that fish spawning lasted longer in waters with higher temperatures.
\end{abstract}

Keywords: climate change, fish, heated lakes, reproductive timing, spawning, temperature

Climate change has piqued the interest of biologists in the impact of temperature and associated environmental changes on the key elements of the fish life cycle (Nunn et al. 2007, Krabbenhoft et al. 2014). Long-term ecology studies suggest that climate change has a significant impact on the population

\footnotetext{
A. Kapusta $\left[\square^{\circ}\right]$

Department of Hydrobiology

Inland Fisheries Institute, Olsztyn, Poland

e-mail: a.kapusta@infish.com.pl

E. Bogacka-Kapusta

Department of Ichthyology, Inland Fisheries Institute in Olsztyn,

Poland
}

structure of fish (Jeppesen et al. 2012) and elements of the fish life cycle (Crozier and Hutchings 2014). Increased water temperatures and shortened winters result in spawning beginning earlier and shorter incubation times in fish that spawn in the spring and delayed spawning in fish that reproduce in the fall (Lyons et al. 2015). Heated lakes provide good conditions for verifying empirically what impact water thermal regime has on fish populations. Studies to date that have been done in lakes into which power plants discharge post-cooling waters have indicated that the life cycles of many fish species are affected significantly (Zawisza and Backiel 1972). The aim of the current paper is to present the results of studies of the phenology of the spawning of fish in two lakes that differ in the degree of water heating to which they are subjected.

The study area was two lakes that are heated to different degrees by two power plants (Kapusta and Bogacka-Kapusta 2015). Lake Licheńskie has been heated since 1958. Post-cooling waters are discharged into this lake throughout the year. Since 1970, Lake Ślesińskie has received waters from lakes Licheńskie and Mikorzyńskie, where the waters are cooled initially. Water heating has been irregular from the very beginning. In the past fifteen years, the lakes have only been heated during the warmest months of the year, usually from June to August. As a consequence of discharging power plant heated

\footnotetext{
(C) Copyright by Stanisław Sakowicz Inland Fisheries Institute in Olsztyn.

(c) 2016 Author(s). This is an open access article licensed under the Creative Commons Attribution-NonCommercial-NoDerivs License (http://creativecommons.org/licenses/by-nc-nd/3.0/).
} 


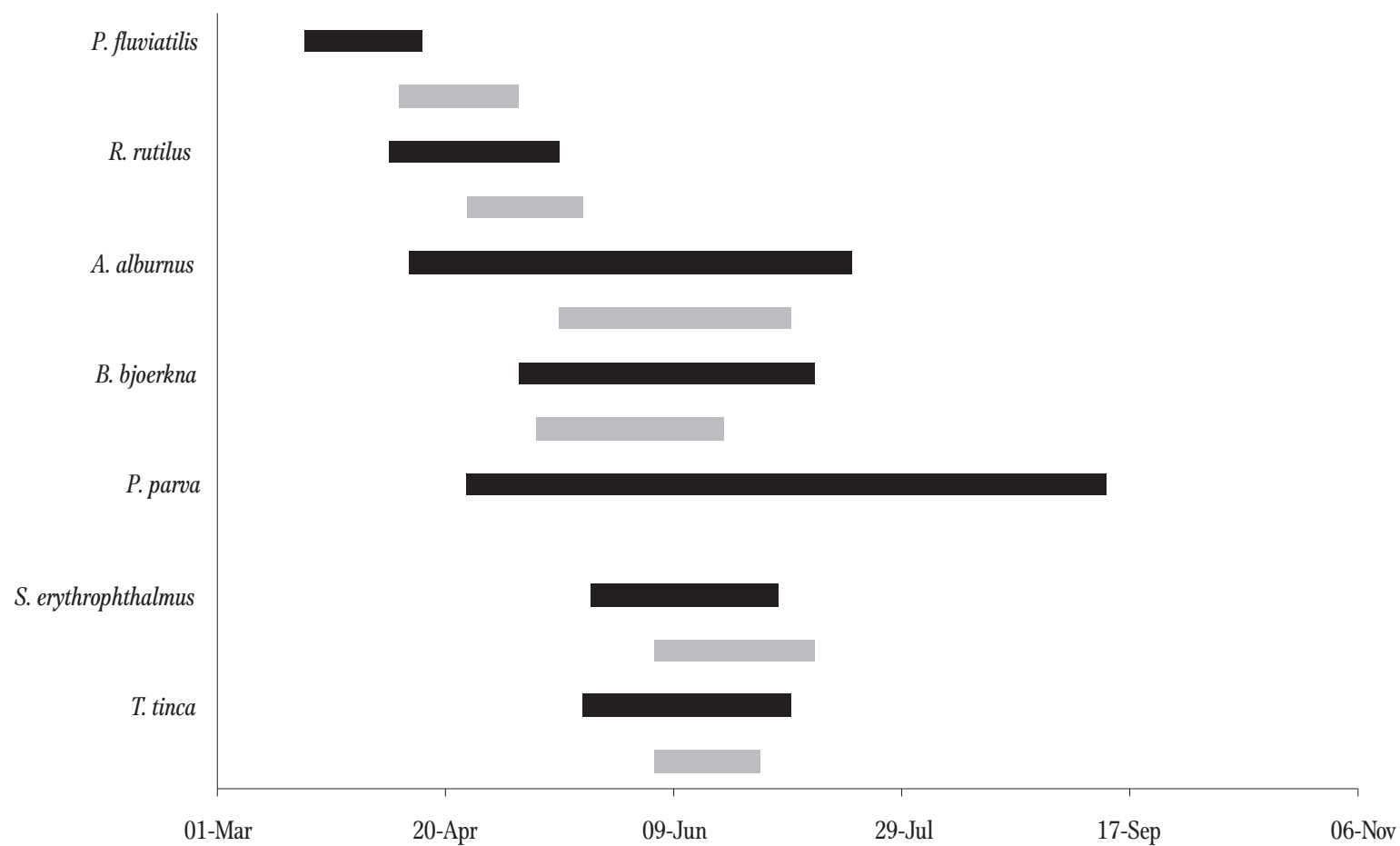

Figure 1. Dates of spawning and the appearance of the larvae of seven fish species in the first stages of development in lakes Licheńskie (black) and Ślesińskie (gray).

waters into the lakes, the mean water temperature in some lakes increased significantly. The degree of heating in the lakes differed (Stawecki et al. 2013). In the warmest lakes (Licheńskie, Gosławskie, Pątnowskie), the water did not freeze in winter, while in summer the temperature in the littoral zone reached approximately $30^{\circ} \mathrm{C}$. Among the five lakes in the complex, Lake Ślesińskie has the coolest water temperatures (Stawecki et al. 2013).

Observations of spawning were conducted in the littoral zone of lakes Licheńskie and Ślesińskie from 2000 to 2007. The shore zone was searched for spawning sites, and fish were caught with fine-mesh nets (mesh size $1 \mathrm{~mm}$ ). The period and course of spawning was determined through direct observations and by analyzing the larval fish caught (Wilkońska and Żuromska 1967). From mid-April to mid-June, fish were caught weekly, then from July to October they were caught once or twice monthly. The larvae caught were preserved in a $4 \%$ formaldehyde solution. In the laboratory, the fish were identified to the species, body length measurements (standard length SL) were taken, and they were classified by developmental stages (Koblickaya 1966, Pinder 2001).

Thirty-five fish species were confirmed to occur in the heated lakes complex (Tereshchenko et al. 2007, Kapusta and Bogacka-Kapusta 2015). All of the species occurring in the lakes studied spawn in the spring-summer period. Most of the species noted occurred in small numbers, and during the study it was not possible to establish the precise dates of their spawning. For most of the species, the spawning sites were not identified, but in several places larvae in the first and second stages of development were caught. The spawning sites and periods were identified for seven species (Fig. 1). The larvae of these species were caught in large enough numbers that is was possible to determine when spawning began and how long the reproduction period lasted. The species that began spawning the earliest included perch, Perca fluviatilis L., while those that began spawning the latest were rudd, Scardinius erythrophthalmus (L.), tench, Tinca tinca (L.) (Fig. 1). Topmouth gudgeon, Pseudorasbora parva (Temminck and Schlegel), stood out as the species with the longest 
spawning period, which, in Lake Licheńskie, began in the second half of April and lasted until mid-September. The spawning period of $P$. parva that was established based on catches of larval fish was significantly longer than that determined based on detailed studies of the gonadosomatic index of this species from Lake Licheńskie (Záhorská et al. 2014). Small numbers of larval P. parva in the first and second stages of development were caught as late as in September, but no adult females ready to spawn were caught at this time. In Lake Slesińskie, this species has occurred in small numbers since 2006 (Kapusta and Bogacka-Kapusta 2015), which is why it was not possible to determine the timing of its spawning.

Spawning in Lake Licheńskie, which is heated to a greater degree, usually takes place two to three weeks earlier than in Lake Ślesińskie. Perch, rudd, and roach, Rutilus rutilus (L.) finished spawning earlier in Lake Licheńskie, while bleak, Alburnus alburnus (L.), silver bream, Blicca bjoerkna (L.), and tench all began spawning earlier and finished spawning later in the more heated Lake Licheńskie. Batch spawning species had the longest reproductive periods. In the more heated lake, the batch spawning fish reproduced nearly twice as long as those in the lake with a natural thermal regime. In comparison to similar studies conducted in 1966-1969, significant differences were noted with regard to spawning period. In Lake Licheńskie the fish began spawning approximately a month later than is reported by Wilkońska and Żuromska (1977). For example, in 1967 bleak spawning in Lake Licheńskie ran from February to September, while in the 2000-2007 period it ran from mid-April to the end of July. The differences noted could have been caused by decreased heating in the lakes (Stawecki et al. 2013), and it could be an adaptation to significantly altered environmental conditions.

Temperature affects a myriad of biological processes, including individual growth, and changes in life history traits. These studies indicate that heating the lake waters had a distinct impact on accelerating fish spawning periods in comparison to those same species inhabiting lakes with natural thermal regimes. Additionally, it was noted that fish spawning lasted longer in lakes with higher water temperatures.

Acknowledgements. The study was conducted within the framework of the statutory research program of the Inland Fisheries Institute in Olsztyn (No. S009) and project number 3P06Z02024.

Author contributions. A.K. designed the research; A.K and E.B.K. performed the research, and wrote the paper.

\section{References}

Crozier L.G., Hutchings J.A. 2014 - Plastic and evolutionary responses to climate change in fish - Evol. Appl. 7: $68-87$.

Jeppesen E., Mehner T., Winfield I.J., Kangur K., Sarvala J., Gerdeaux D., Rask M., Malmquist H.J., Holmgren K., Volta P., Romo S., Eckmann R., Sandström A., Blanco S., Kangur A., Stabo H.R., Tarvainen M., Ventelä A.-M., Søndergaard M., Lauridsen T.L., Meerhoff M. 2012 Impacts of climate warming on the long-term dynamics of key fish species in 24 European lakes - Hydrobiologia 694: 1-39.

Kapusta A., Bogacka-Kapusta E. 2015 - Non-native fish species in heated lakes: Origins and present status - Arch. Pol. Fish. 23: 121-129.

Koblickaya A.F. 1966 - A key for determination of young fishes of the Volga estuary - Publishing house Nauka, Moskva: 1-166 (in Russian).

Krabbenhoft T.J., Platania S.P., Turner T.F. 2014 Interannual variation in reproductive phenology in a riverine fish assemblage: implications for predicting the effects of climate change and altered flow regimes Freshw. Biol. 59: 1744-1754.

Lyons J., Rypel A.L., Rasmussen P.W., Burzynski T.E., Eggold B.T., Myers J.T., Paoli T.J., McIntyre P.B. 2015 - Trends in the Reproductive Phenology of two Great Lakes Fishes - Trans. Am. Fish. Soc. 144: 1263-1274.

Nunn A.D., Harvey J.P., Britton J.R., Frear P. A., Cowx I.G. 2007 - Fish, climate and the Gulf Stream: the influence of abiotic factors on the recruitment success of cyprinid fishes in lowland rivers - Freshw. Biol. 52: 1576-1586.

Pinder A.C. 2001 - Keys to larval and juvenile stages of coarse fishes from fresh waters in the British Isles - Scientific Publication. No 60. Ambleside: Freshwater Biological Association, $136 \mathrm{p}$. 
Stawecki K., Zdanowski B., Pyka J.P. 2013 - Long-term changes in post-cooling water loads from power plants and thermal and oxygen conditions in stratified lakes Arch. Pol. Fish. 21: 331-342.

Tereshchenko V.G., Kapusta A., Wilkońska H., Strelnikova A.P. 2007 - Long-term changes in 0+ fish assemblages in the littoral zone of heated lakes. I. Diversity, evenness and dynamic phase portrait of species structure - Arch. Pol. Fish. 15: 415-430.

Wilkońska H., Żuromska H. 1967 - Observations of the spawning of pike (Esox lucius L.) and roach (Rutilus rutilus L.) in Mazury Lake district - Rocz. Nauk Rol. 90-H-3: 477-502 (in Polish with English summary)

Wilkońska H., Zuromska H. 1977 - Observations of the reproduction of fish in the Konin lakes complex heated by power plant post-cooling waters - Rocz. Nauk Rol. 97-H-4: 77-89 (in Polish with English summary).

Záhorská E., Kováč V., Švolíková K., Kapusta A. 2014 Reproductive parameters of topmouth gudgeon (Pseudorasbora parva) from a heated Lake Licheńskie (Poland) - Cent. Eur. J. Biol. 9: 212-219.

Zawisza J., Backiel T. 1972 - Some results of fishery biological investigation at heated lakes - Verh. Int. Verein. Limnol. 18: 1190-1197. 